
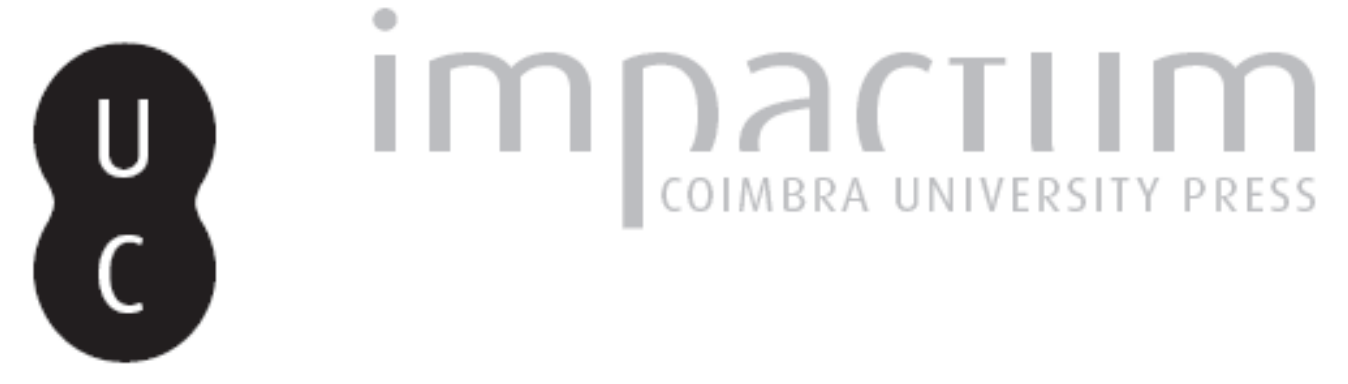

\title{
O espelho que sangra: representações ficcionais da história
}
Autor(es):
Bebiano, Adriana
Publicado por: Instituto de História Económica e Social; Imprensa da Universidade de Coimbra

URL persistente:

URI:http://hdl.handle.net/10316.2/44502

DOI:

DOI:https://doi.org/10.14195/0870-4147_37_10

Accessed : $\quad$ 26-Apr-2023 11:25:25

A navegação consulta e descarregamento dos títulos inseridos nas Bibliotecas Digitais UC Digitalis, UC Pombalina e UC Impactum, pressupõem a aceitação plena e sem reservas dos Termos e Condições de Uso destas Bibliotecas Digitais, disponíveis em https://digitalis.uc.pt/pt-pt/termos.

Conforme exposto nos referidos Termos e Condições de Uso, o descarregamento de títulos de acesso restrito requer uma licença válida de autorização devendo o utilizador aceder ao(s) documento(s) a partir de um endereço de IP da instituição detentora da supramencionada licença.

Ao utilizador é apenas permitido o descarregamento para uso pessoal, pelo que o emprego do(s) título(s) descarregado(s) para outro fim, designadamente comercial, carece de autorização do respetivo autor ou editor da obra.

Na medida em que todas as obras da UC Digitalis se encontram protegidas pelo Código do Direito de Autor e Direitos Conexos e demais legislação aplicável, toda a cópia, parcial ou total, deste documento, nos casos em que é legalmente admitida, deverá conter ou fazer-se acompanhar por este aviso. 


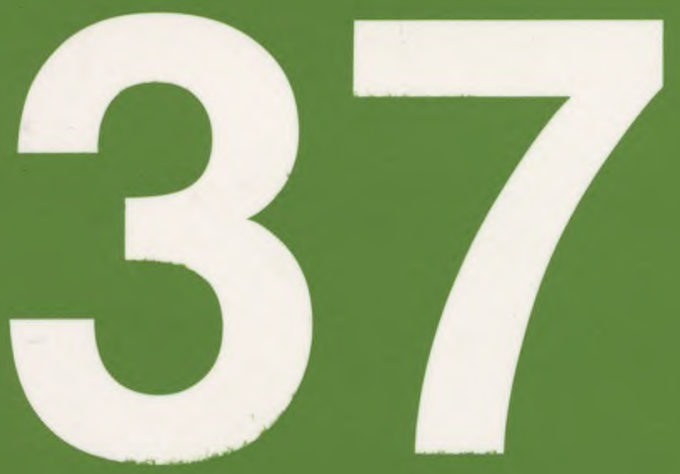

Revista Portuguesa de História

Faculdade de Letras da Universidade de Coimbra Instituto de Historia Econónica e Samial

Coimbra 05 


\section{O espelho que sangra: representações ficcionais da história*}

Adriana Bebiano

FLUC E CES

O sangue das crianças é como...

o sangue das crianças

Pablo Neruda

History is what hurts.

Frédéric Jameson

1. A cor do sangue

Nos versos de Neruda, que escolho para início desta reflexão, encontram-se formuladas duas questões incontomáveis para a literatura do nosso tempo. A primeira, diz respeito à possibilidade da representação do sofrimento - ou, mais exactamente, aos limites da sua representação. Neruda sugere a impossibilidade da metáfora, que finge querer enunciar no primeiro verso. As reticências sinalizam a hesitação, o (fingido) momento de procura do flaubertiano mot juste. Mas em vez de desembocar na "palavra exacta" a hesitação é seguida pela repetição literal

* Investigação efectuada no âmbito do projecto "Representações da violência e a violência das representações" (Centro de Estudos Sociais, Universidade de Coimbra), financiado pela F.C.T. 
da enunciação inicial, deixando assim clara a impossibilidade de se encontrar urna palavra ou expressão que substitua, com vantagem, "a coisa em si”. A experiência do sangue só pode ser representada pelo próprio sangue. Acresce que, na recusa da metáfora para o sangue das crianças, se encontra ainda a objecção ética para o recurso à metáfora como forma de figurar a experiência do sofrimento. De facto, a segunda questão que estes versos colocam é de cariz político e ético: até que ponto é legítimo usar a experiência do horror como matéria para a literatura? Dito de outro modo, até que ponto é legítimo transformar a experiência do sofrimento em experiência estética?

A questão da legitimidade da representação da violência tomou-se particularmente premente na sequência da segunda guerra mundial, em particular em tomo das representações do holocausto. Na muito citada e discutida afirmação de Adomo, exemplar da discussão sobre esta questão no pós-guerra, depois de Auschwitz escrever poesia seria um acto de barbárie.' Se a poesia é sinal de cultura versus animalidade, isto é, se a poesia significa o humano por excelência, Auschwitz é a sua negação, ou o colapso do humano. O horror dos campos toma espúria a escrita poética, na medida em que esta não representa - não toma compreensível - o acontecido. Por outro lado, a realidade de Auschwitz exemplifica de forma inequívoca a impossibilidade da representação (fiel), condenada a ficar sempre aquém da experiência.

E, no entanto, seis décadas mais tarde multiplicam-se as representações de Auschwitz, sendo mesmo o holocausto matéria de uma indústria que se mantém próspera, tanto na produção literária como na cinematografia. Se a reconfiguração de uma experiência-limite, sob a forma narrativa ou de poema, é sempre já reconfiguração, a consciência deste limite não conduz ao silêncio. Estamos perante um paradoxo, que António Sousa Ribeiro formula do seguinte modo: "No extremo, a violência não consente a linguagem, admite apenas formas de expressão elementares e inarticuladas como o grito. (...) No entanto, pode dizer-se desde sempre a violência foi tema da literatura. Isto é, formulado de outro modo, desde sempre a literatura soube construir modos de significar a violência (Ribeiro, 2000: 200).

No que diz respeito à narrativa de eventos históricos coloca-se ainda o problema da importância da memória. Ora, o silêncio, enquanto alternativa à representação desses eventos, ainda que representação imperfeita e incompleta, seria uma espécie de cumplicidade com a violência perpetrada. Richard Keamey coloca esta questão de forma muito clara: "narrative memory seeks to preserve some trace of those 1

\footnotetext{
"nach Auschwitz ein Gedicht zu schreiben, ist barbarisch." A frase surge no ensaio "Kulturkritik und Gesellschaft", de 1951 (in Petra Kiedaisch, 1995).
} 
others - especially victims of history - who would, if unremembered, be lost to the injustice of non-existence." (Keamey, 2003: 80). O silenciamento das vitimas apaga-as da memória colectiva, condena-as à não-existência. $O$ poeta Seamus Heaney, nativo do Ulster, uma região do globo em estado de guerra intermitente desde há oito séculos, expressa bem a necessidade de prestar testemunho do sofrimento, em North: "What do I say, if they wheel out their dead?" Trata-se de uma pergunta em larga medida retórica, uma vez que, perante os corpos das vítimas impõe-se o imperativo ético de falar, mesmo antes de se saber que forma exacta - "what"? - pode ter essa fala.

Existe ainda um outro paradoxo no sofrimento transformado em objecto estético ou espectáculo: o que dói ver, é ainda objecto de desejo do olhar, e é ainda irresistível dar a ver. ${ }^{2}$ Daí que não surpreenda que a dor não conduza ao silêncio, mas sim à multiplicação das vozes. De resto, a dor - o sangue, o sofrimento humano - é musa antiga. Pois que outra coisa canta a Ilíada se não o sangue e os corpos deslassados pela mão humana?

A questão ética emerge justamente da vertente estética das representações. Toda a reconfiguração comporta uma dimensão estética, quero dizer, transforma a experiência em objecto estético. Mesmo no caso da escrita memorialista, não se trata de simples testemunho, ou "objecto encontrado" do que aconteceu, mas objecto-outro, que é fonte de prazer para quem lê. Visto que o prazer que provoca é indissociável da própria definição do objecto estético em que toda a representação se transforma, coloca-se o problema ético: como aceitar a transformação da dor de um corpo em fonte de prazer de outros corpos?

$\mathrm{Na}$ verdade, esta é uma operação que se faz todos os dias, de forma mais ou menos inconsciente, e mesmo naturalizada. Para dar um exemplo simples, basta lembrar os prémios da World Press Photo : todos os anos os seus primeiros prémios, em quase todas as categorias, são atribuídos a imagens de sofrimento extremo nas quais a dimensão estética se sobrepõe à dor retratada. ${ }^{3}$

De facto, representações de violência de todo o tipo saturam o nosso quotidiano e são consumidas com prazer. Kristeva oferece uma explicação para o fenómeno: "The media propagate de death instinct. Look at the films people

2 O locus classicus deste paradoxo pode encontrar-se nas páginas iniciais de Vigiar e Punir, onde é descrita a última execução pública na França do Ancien Régime, com pormenores do suplício e o deleite dos espectadores. No domínio das representações artísticas, a categoria estética que melhor expressa este paradoxo é o grotesco. Para uma discussão do seu carácter paradoxal, veja-se Alonso, 2001.

3 Uma visita à página dos prémios atribuídos em 2005 pode ser efectuada em www.worldpressphoto.nl. 
like to watch after a long tiring day: a thriller or a horror film, anything less is considered boring. We are attracted to this violence." (appud Keamey, 2003: 9) Trata-se, portanto, de uma contemplação que de alguma forma satisfaz a pulsão da morte. De resto, só o conflito gera narrativas. O lugar-comum segundo o qual "os povos felizes não têm história" tem implícita a ideia da indissociabilidade entre "violência" e "acontecimento histórico notável", isto é, aquele que vale a pena contar. Convergem aqui os dois significados de "história": o acontecimento ou evento, e o conto que sobre ele se tece, que dá prazer no acto de contar e de ouvir contar.

$\mathrm{Na}$ confluência entre estes dois significados de "história" encontra-se o romance histórico, que transforma acontecimentos e personagens com existência história real em experiência estética. Ora, este tipo de romance centra-se justamente em momentos de grandes mudanças e transformações, por regra situações de guerra, épocas de repressão ou erupções de conflitos. E é justamente a natureza violenta ou conflituosa da história que a toma matéria tão apetecível à ficção. $\mathrm{O}$ que Kristeva afirma genericamente sobre as ficções cinematográficas que ocupam os serões de uma fatia significativa das pessoas comuns é também observável ao nível da produção do romance histórico, onde a figuração da violência funciona como uma mais valia. De facto, "anything else is boring" \{ibidem), produz apenas tédio. Num presente que carece de peripécias, o romance histórico pode funcionar como uma fuga para um passado que imaginamos mais excitante, ou que é representado como tendo sido mais excitante, com uma componente importante de aventura. Esta viagem ao passado tem também a sua componente de nostalgia, mesmo quando esse passado é representado como carregado de perigos e crueldades várias. A nostalgia não será, naturalmente, por um tempo marcado pela morte e pelo sofrimento, mas sim por um tempo marcado pelas situações de excepção, um tempo em que imaginamos que os actos heroicos eram possíveis. A uma distância cómoda, a intensidade dos tempos terríveis é preferível ao tédio dos dias banais.

No entanto, o escapismo ${ }^{4}$, ou a capacidade de fuga do real, é apenas uma das vertentes que contribui para a actual popularidade do romance histórico. Sendo a única resposta encontrada pelos detractores do género para essa popularidade, trata-se de uma resposta apenas parcial para uma questão complexa.

\footnotetext{
Por "escapismo" ou "literatura escapista" entende-se toda a narrativa que tenha uma (aparente) desvinculação do real, como, por exemplo, os romances de aventuras ou a ficção científica. O termo tem uma carga pejorativa e pressupõe ainda a ideia de um cânone literário fixo e imutável, do qual todos os textos escapistas seriam, naturalmente e para sempre, excluídos.
} 
De facto, ao responder à pulsão da morte, estes romances cumprem ainda uma função catártica, cuja importância se reconhece desde a Poética de Aristóteles (veja-se Poética, 1449b). ${ }^{5} \mathrm{Na}$ verdade, o efeito de catarse não se encontra exclusivamente na tragédia clássica, contexto no qual Aristóteles o discute, mas está presente nas representações da violência em geral, mesmo em versões light, como o romance de aventuras ou o histórico de aeroporto.

Talvez ainda mais importante do que a fuga ao real ou mesmo a função catártica, é o papel da narrativa enquanto modo de fazer sentido da experiência, pessoal ou colectiva. Se a experiência da dor é irrepresentável no seu ser-aí, a dor sem nome, ou a dor antes da representação, é insuportável. Dar nome - isto é, dar uma configuração - à dor é tomá-la compreensível e, nessa medida, suportável. A cura pela fala é, afinal, uma operação que tem vindo a ser feita desde a antiguidade por toda a literatura, muito antes de Freud a ter nomeado e transformado em prática clínica. Transformar a experiência histórica em narrativa é dar-lhe um sentido. Na sua teoria narrativa Frank Kermode explica a necessidade humana de produzir ficções, como uma operação que visa substituir a experiência pelo sentido (Kermode, 1981).

Há, portanto, a necessidade, individual e colectiva, de dar forma à violência historicamente vivida. ${ }^{6}$ As formas encontradas são, no entanto, bem diversas, e têm, naturalmente, efeitos estéticos e políticos diversos. A tradição épica, com o seu cortejo de heróis guerreiros e o seu rosário de mortes violentas, sobrevive no chamado "romance de aventuras". A aventura obriga ao triunfo final do herói, e esse tende a ser representativo de uma nação, grupo étnico, ou comunidade de outro tipo, contribuindo assim para a narrativa identitária da comunidade. Aos eventos históricos é dada a forma de confronto entre o bem e o mal, as mais das vezes sem modalizações ou nuances, com o inevitável triunfo do bem. Este desenlace, obrigatório no género, produz no leitor a satisfação da reafirmação na crença num universo com sentido e no qual a ordem é possível. Subjaz-lhe uma versão optimista da história, que salvaguarda a ideia do progresso humano. Se a aventura inclui a narração do sofrimento - pelo qual tanto herói como personagens coadjuvantes passaram -, trata-se de um sofrimento com sentido: morte e sangue derramado tomam-se aceitáveis, uma vez que são vistos como o preço a pagar pelo triunfo do bem e da civilização. Mesmo quando saturados em sangue,

\footnotetext{
s Para uma discussão do conceito de catarse em Aristóteles, veja-se a Introdução de Eudoro de Sousa in Aristóteles, Poética (Lisboa: Imprensa Nacional - Casa da Moeda, 6a ed., s.d., 98-101).

6 Recorde-se as inúmeras ficções que têm sido produzidas nas últimas décadas, nos Estados
} Unidos, sobre a guerra do Vietname. 
estes romances são objectos de conforto, que confirmam a fé nos valores que, no decurso da aventura, haviam sido colocados em perigo, mas que acabam por triunfar. O género da aventura, no entanto, tem o seu lado escuro: na pacificação final são caladas as vozes dos vencidos, em regra um Outro demonizado ou figurado como monstro. Esta figuração não é inocua, urna vez que é urna estratégia que permite que o silenciamento do Outro possa ser apresentado como acto de justiça e, assim, sentido sem culpa.

Um projecto imperial é, por natureza, violento. Em regra sustentado num discurso de defesa e difusão da civilização (nossa) contra a barbárie (do Outro), não deixa de levar a sua barbárie ao espaço do outro. Walter Benjamin formula esta dupla natureza de forma lapidar. "There is no document of civilization which is not at the same time a document of barbarism." (Benjamin, 1969: 256) Se todos os impérios são fundados no sangue, por outro lado, ñas narrativas que sobre eles se tecem e que os sustentam existe a tendência para estetizar o sangue, o que o toma aceitável e mesmo desejável. Esta operação de estetização não ocorre apenas na representação da morte do outro - monstro, portanto morte não-humana, o que impede a empatia do leitor - mas principalmente na morte do mesmo, ou dos "nossos". A horaciana doçura encontrada na morte pela pátria - dulce et decorum est pro patria mori - permite olhar a morte do herói como esteticamente sedutora. Por outro lado, o sacrificio do herói permite a sua própria redenção ou a redenção da comunidade em nome da qual morre. ${ }^{7}$ Dito de outro modo, se enredada como acto de heroísmo, a morte ganha sentido, e passa mesmo a ser da ordem do sublime, elevando-se o herói acima da condição do comum dos mortais.

Nem toda a representação de violência é, no entanto, da ordem do sublime, ou sequer do espectacular. A representação da violência de excepção mais facilmente produz maior impacto. No entanto, facilmente o leitor ou espectador se habitua a um determinado grau de violência, pelo que se toma necessária uma maior elaboração do espectáculo para manter a intensidade do impacto. Sendo excepcional - corpos mutilados, cadáveres de executados posicionados em formas grotescas - coloca ainda o problema dos limites da eficiência da espectacularidade. Assim, a imagem evocada tem de trazer algo de novo, ou corre o risco de se tomar banal e mesmo "natural".

\footnotetext{
Existe literatura abundante, proveniente de diversas áreas do saber, sobre o valor simbólico da morte como sacrifício que redime a comunidade. Para uma discussão da sua função na obra literária, veja-se, por exemplo, Benjamin, Origem do drama trágico alemão (Lisboa: Assírio e Alvim, 2004).
} 
No caso das ficções históricas colocam-se problemas específicos. Em regra, os traços gerais tanto da trama como das personagens são conhecidas a priori pelo leitor, sendo apenas desconhecidos - funcionando, portanto, como factor de novidade - pormenores e a consciência (Accionada) das personagens. Logo, o guionista ou o romancista não pode contar com a novidade da trama - "o que é que acontece a seguir?" - para produzir o impacto que faça com que o leitor continue agarrado ao livro. ${ }^{8}$ Sabemos que Ana Bolena vai perder a cabeça, que D. João II vai morrer no Alvor, que Cleópatra se vai suicidar com a ajuda da serpente. Daí a necessidade de encontrar estratégias que façam com que o leitor leia, ou veja, uma vez mais uma história cujos contornos e desenlace sobejamente conhece. Para além do talento e da arte de quem escreve, o lugar - isto é, a cultura - de onde escreve vai condicionar a escolha de estratégias a adoptar. A panóplia de estratégias narrativas possíveis é múltipla e enunciarei apenas algumas das mais usadas e determinantes na construção do significado.

\section{Velhas histórias sob novas capas}

Recorrendo a um exemplo pertencente à história europeia do século XX, lembro a proliferação de narrativas sobre o Holocausto, que continuam a ser produzidas e consumidas sem que necessariamente tragam conhecimento acrescido. A magnitude da violência cometida e sofrida não é explicação cabal para a multiplicação da produção, nem o continuado consumo, de narrativas já antigas e sobejamente conhecidas. As narrativas vendem, porque contam uma boa história, isto é, contam uma velha história com uma configuração atraente. Ora, para ter poder de atracção, as velhas histórias têm de conter algo de novo.

Uma estratégia ffequentemente usada para criar a ideia do novo é a adopção da perspectiva do "outro lado", isto é, dos intervenientes até então calados. Lembro o filme Der Untergang, que em português tem o título A Queda - Hitler e ofim do Terceiro Reich, do realizador Olivier Hirschbiegel, estreado em 2004. Neste filme são narrados os últimos dias antes da conquista de Berlim pelo Exército Vermelho, do ponto de vista dos habitantes do bunker onde se encontra Adolf Hitler, com os seus colaboradores mais próximos. Trata-se de uma velha

\footnotetext{
8 De resto, é justamente na figuração estética e altamente elaborada dos corpos torturados que está uma das razões - embora não a única - do êxito actual de $O$ Código da Vinci. Não se trata, em rigor, de um romance histórico, uma vez que a sua componente esotérica o coloca para além das fronteiras do género (sobre a gramática do género, veja-se Bebiano, 2003). Não deixa, no entanto, de ser classificado pelo leitor comum, apresentado pela publicidade e posicionado nas livrarias, como romance histórico.
} 
e conhecida historia, portanto, mas que, na sequência da derrota alemão, tem sido tendencialmente narrada do ponto de vista dos vencedores, pelo que o factor "novidade" é encontrado na adopção de um ponto de vista menos comum. 9 Esta escolha tem consequências nas leituras da narrativa, inevitavelmente polémicas. Tendo o nazismo adquirido o significado comum de manifestação literal do Mal, a narração da história do ponto de vista nazi levanta a questão da possibilidade do seu branqueamento. De facto, "A Queda" representa Hitler como sendo, apesar de tudo, humano, desde logo pelo corpo fragilizado, na mão que treme em consequência da doença de Parkinson. Ora, uma representação que não o apresente literalmente como monstro - isto é, radicalmente não-humano - não pode deixar de perturbar, uma vez que se afasta das representações dominantes e moralmente sancionadas na nossa actualidade. A celeuma gerada pelo filme é sintoma da eficiência da estratégia de "contar do outro lado" enquanto criadora de perturbação das representações hegemónicas num determinado momento histórico.

Uma segunda estratégia narrativa muito comum, e eficiente na criação do efeito do novo enquanto se conta o velho, é o enfoque num indivíduo comum, por contraste com as figuras de um protagonista com contornos heroicos. Este enfoque permite a ocorrência da empatia, isto é, em termos estéticos, uma identificação por parte do leitor ou espectador com a personagem. Se a personagem em causa é uma das vítimas, a identificação funciona mais facilmente; de resto, é necessária à catarse. Nada muda no relato da trama principal ou das partes cerimoniais da história, as quais, sendo reconhecidas, funcionam apenas como pano de fundo ou cenário para o drama que se desenrola em primeiro plano. No caso da representação da violência, a especificidade do sofrimento encontra-se na especificidade do corpo que o sofre. Dito de outro modo, não se trata do sofrimento em forma pura e abstracta, desvinculado de um corpo e de uma consciência, mas do sofrimento que é infligido a um corpo concreto e que o leitor sente como real, pela projecção na personagem. Neste caso, a espectacularidade é mesmo dispensável, uma vez que não reside no espectáculo o eixo da narrativa, mas na cumplicidade que se estabelece entre leitor e personagem. Lembro aqui dois livros que se têm mantido no centro do cânone das representações da violência

9 A principal fonte para o guião do filme é a narrativa autobiográfica de Traudl Junge, uma das secretárias de Hitler durante aqueles dias, o que lhe garante o grau de autoridade próprio do testemunho e, concomitantemente, faz esquecer a sua componente ficcional. Inside Hitler $s$ Bunker: The Last Days of the Third Reich, da autoria do historiador Joachim Fest, é uma outra fonte importante. 
nazi: Se isto è um homem, de Primo Levi, com uma primeira edição italiana de 1958, e o Diário, de Anne Frank, com a primeira publicação holandesa em 1947. Ambos têm tido sucessivas edições nas línguas mais diversas e, no entanto, trata-se de dois livros que não contêm qualquer violência espectacular, nada de visualmente apelativo ou chocante.

Se Isto é um Homem relata a vida quotidiana nos campos de extermínio em tom neutro, apagados todos os traços de emoção. As acções que apresenta são aparentemente insignificantes: as filas na hora das refeições e o que lá se fazia ou dizia, os estratagemas para obter mais uma côdea de pão ou a parte mais grossa da sopa, a importância de uma pequena medida de cordel na "bolsa de valores" do campo. Coisas de nada, nem sombra de gestos heroicos, nem cheiro de aventura; nada de uma grandeza que permita pensar qualquer parentesco com a tragédia, por exemplo, ou com as narrativas neo-épicas que a guerra gerou. Porquê então o continuado impacto do livro? Foi escrito por um sobrevivente dos campos, o que lhe confere, portanto, o valor acrescido de testemunho ou de "verdade". No entanto, há um sem-número de outros relatos autênticos que nunca deixaram a obscuridade, e que são lidos apenas por um número reduzido de estudiosos ou curiosos deste tipo de literatura. Porquê ainda o sucesso do Diário de Anne Frank, também ele sem violência espectacular? Afinal, trata das coisas vulgares de uma adolescente comum: a atenção ao corpo que muda, a sexualidade que desponta, a importância de um vestido novo, quase futilidades. Poder-se-ia argumentar - e com razão - que ambos tratam das banalidades do quotidiano, mas de um quotidiano vivido em condições de excepção. Ora, é justamente aí, na capacidade da sobrevivência da banalidade e das pessoas comuns em situações de excepção, que reside o seu poder, uma vez que são os gestos do quotidiano que estabelecem a relação de continuidade, ou, dito de outro modo, a possibilidade de projecção, entre o leitor e as personagens. Ambos representam a violência não pela sua presença espectacular, mas pela ausência dos confortos mínimos que distinguem o humano daquilo a que Agamben chama "a vida nua" (Agamben, 1998), seja, no caso de Frank, na (im)possibilidade de sair até à rua ver uma árvore no despontar da primavera, seja, no caso de Levi, as operações mentais e a contenção necessárias para não ser o homem cuja urina acaba por encher o balde comum durante a noite. Trata-se de um detalhe importante, uma vez que esse homem teria de ir à rua despejar o balde, operação impossível de realizar sem derramar alguma urina sobre os pés.

O pormenor prosaico da urina nos pés não tem um potencial visual que contribua, de forma significativa, para a construção do nazismo como manifestação do Mal. Seria difícil usá-la na iconografia sobre a matéria sem uma paráfrase explicativa da sua importância. Mas é justamente este tipo de 
detalhe, aparentemente insignificante, que mima narrativa permite estabelecer a ligação entre o leitor, instalado na sua leitura confortável, e Levi em Auschwitz. A representação do quotidiano despido das pequenas coisas que o caracterizam, e que temos por adquiridas, cria uma proximidade entre o protagonista da narrativa e o leitor, activando os seus medos e permitindo, assim, a emoção que serve de sintoma para o impacto estético. A cumplicidade entre o leitor e Levi, ou entre o leitor e Frank, está nas coisas banais do quotidiano que partilham e reconhecem. Por outro lado, as situações de excepção surgem-nos como desvinculadas da realidade e produzem um efeito de distanciamento no acto de leitura. Por muito verdadeiras que sejam, são percepcionadas como ficção: para o leitor, só acontecem nos filmes, nos romances, ou em lugares e tempos muito distantes. Mais do que o gesto espectacular, o pequeno gesto quotidiano banal, quando usado na representação da violência, potencia o seu impacto.

A identificação é facilitada quando a narrativa cria o que Barthes chama "o efeito do real" (Barthes: 1968). Este efeito pode ser produzido em todo o tipo de narrativas, inclusive fantasias inverosímeis, e pode ser provocado de diversas formas. Por exemplo, pela construção de um mundo da narrativa com semelhanças ao mundo do leitor, elidindo assim a distância entre os dois, ou ainda pela inclusão de detalhes verosímeis que estabelecem a ponte entre o mundo da narrativa e o real empírico. No ensaio referido, Barthes fala justamente da inclusão de um pormenor desnecessário à acção, aparentemente inútil e gratuito, que não acrescenta conhecimento algum, mas que funciona como autenticação do universo criado pela escrita. A urina nos pés, no relato de Levi, seria um bom exemplo. É esse pormenor que lembra ao leitor a "realidade" do corpo humano que sofre, permitindo a projecção/identificação, criando assim o sofrimento no acto de recepção, e arrancando aquele prisioneiro ao anonimato de todos os prisioneiros.

Esta estratégia é tão velha quanto a literatura ocidental. Na Ilíada - o primeiro texto literário da tradição ocidental - ocorre frequentes vezes. Para vermos claramente como formas diversas de representar a violência produzem efeitos diversos, lembremos a Ilíada. Nas muitas cenas de combate que inclui, ouve-se repetidamente os seguintes versos: "Então se ouviu o gemido e o grito triunfal dos homens / que morriam e eram mortos. A terra ficou alagada de sangue."10 Nestes versos existe sangue em abundância e os ruídos que acompanham a morte. No entanto, a pluralidade e o anonimato das vozes não convida à identificação; a visão é panorâmica e distanciada e dela não sobressai nenhum pormenor que estabeleça a continuidade entre as personagens e o leitor. Tudo isto aconteceu

10 Uso a versão de Frederico Lourenço (Lisboa: Cotovia, 2005). Os versos citados encontram-se, por exemplo, em IV, 450-451 e em VIII, 64-65, entre outros lugares. 
há muito tempo, noutro lugar, a personagens que reconhecemos de um universo que sabemos ficcional. Por outro lado, a Ilíada tem passos que criam a identificação com personagens que reconhecemos apenas do universo ficcional, isto é, que têm justamente o mesmo estatuto ontológico das personagens anónimas dos versos citados. O canto décimo - o mais gore, ${ }^{u}$ segundo Lourenço - tem disso abundantes exemplos, que incluem a mutilação de cadáveres. Porque o gore inclui uma dimensão de espectacularidade visual, em si mesmo geradora de impacto, escolho um exemplo de um combate "banal" como outra estratégia possível para a produção do impacto estético.

Encontra-se no canto quinto, mais exactamente no momento em que Tidida Diomedes pegou numa rocha " e com ela atingiu Eneias na anca, no sítio onde a coxa / se junta à anca, osso a que os homens chamam 'a taça'./ E estilhaçou a 'taça', dilacerando também ambos os tendões./A rocha lacerante rasgou-lhe a carne; o herói caiu de joelhos/ e com a mão possante se recostou contra a terra. / A escuridão da noite veio cobrir-lhe os olhos." (V, 305-310) É no pormenor da localização anatómica exacta do osso atingido, e no preciosismo na sua denominação, em nada necessários para a cena em termos de acção, que reside a possibilidade de identificação. Todos reconhecemos "a taça" no nosso próprio corpo, pelo que podemos assim sentir (o medo da dor) do estilhaçar "no osso que junta a coxa à anca". Eis um bom exemplo do "efeito de real": o pormenor presentifica uma dor acontecida há muito tempo, em combates que nem sabemos se na verdade aconteceram, enquanto sabemos que não aconteceram assim. E, no entanto, o nome e o lugar do osso fazem com que sintamos esta dor como autêntica.

Estas estratégias de representação da violência que a presentificam, explicando assim o seu impacto no acto de leitura, têm em comum o enfoque no corpo. Ora, a história narrativa é tendencialmente uma representação de "feitos". Parece-me que o romance histórico funciona - quero dizer, atrai leitores - na medida em que é capaz de colocar o corpo no seu centro, e através dessa representação criar uma empatia que nos perturbe e nos leve a questionar representações herdadas, as mais das vezes a traço grosso ou sob formas abstractas, distanciadas da nossa realidade. Se a narrativa literária é espelho do real - embora espelho refractor quando o corpo sangra, é necessário que o espelho, de alguma forma, sangre também. ${ }^{11}$

11 "Gore" significa literalmente "sangue", mais exactamente sangue em coagulação e resultante de uma ferida. Usa-se ainda, também em português, para qualificar textos ou passos em que o sangue abunde. 


\section{O portugués sentimental}

Se a historia é matéria fértil para a ficção, de uma mesma matéria emergem configurações diversas, as quais frequentemente reflectem muito mais o tempo e a ideologia que as escreve do que o tempo sobre o qual escrevem. Toda a escrita sobre o passado é também uma escrita sobre o presente, e as reconfigurações encontradas para feitos do passado traduzem práticas e formas de o presente se auto-imaginar.

Desde a década de 1990 que assistimos à proliferação e crescente popularidade do romance histórico, a uma escala quase global, fenómeno este que se verifica também na literatura em português. Trata-se de um fenómeno complexo, que terá várias explicações possíveis, e nas quais, naturalmente, se incluirá a importância do mercado. No entanto, há que ressalvar que o mercado é também criado pelo sucesso do produto e lembrar que, quando o fenómeno se toma visível, na década de 1990, este era um género circunscrito a meia dúzia de autores e quase sempre a livros "de aeroporto" que não gozavam de prestígio entre as elites intelectuais. ${ }^{12}$ Entre os inúmeros romances deste tipo, publicados nas duas últimas décadas, em português ou sobre a história de Portugal, encontram-se romances de qualidade diversa. Para efeitos deste ensaio, porém, interessa-me abordá-los como sintomas da diversidade de reescritas do passado, muito mais do que segundo o seu eventual valor estético, questão de resto muito poucas vezes consensual.

Um dos aspectos curiosos nas várias reconfigurações actuais do passado é a persistência da figura do herói, bem como a persistência da centralidade da Expansão no imaginário português (veja-se Bebiano, 2002). À mitologia nacional que o Estado Novo em larga medida contribuiu para reforçar e transformar em alicerce do imaginário da nação, sucedeu o que Eduardo Lourenço denomina de "contramitologia" (Lourenço, 1978) nos anos pós-revolução. De facto, nesses anos, a ficção portuguesa revisitou a nossa história dando a ver, segundo Isabel Allegro Magalhães, "o esvaziamento e os estilhaços de antigos mitos fundadores" (Magalhães, 2000: 312). O aspecto curioso, no entanto, reside na persistência de uma matriz muito próxima dos mitos fundadores, que vão sendo readaptados à(s) realidade(s) presente(s). No entanto, se o heroísmo da aventura marítima portuguesa persiste, não deixam de ser diferentes as tramas e as configurações desses heróis, cuja construção foi, e vai sendo continuamente, adaptada ao

12 O romance histórico nunca deixou de ser escrito e lido. No entanto, durante décadas, os romances desse tipo que ganharam lugar no cânone não eram pensados enquanto pertencentes ao género, mas sim inseridos em outras categorias ou enquanto romances tout court. Basta lembrar Memorial do Convento (1982), de Saramago, ou Memórias de Adriano (1955), de Yourcenar. 
tempo que os escreve. Uma das características muito presente nas reformulações em curso é justamente a sua adaptação à metanarrativa do multiculturalismo, que de alguma forma se tomou hegemónica no ocidente. Isto traduz-se na representação da Expansão como "encontro de culturas", formulação esta que tende a apagar a violência presente no processo de colonização. Se este tipo de representação tem a bondade evidente do reconhecimento da subjectividade do Outro, funcionando de alguma forma como um acto de "justiça poética", pode funcionar, por outro lado, como ainda uma forma de silenciamento desse mesmo Outro.

Ao valorizar a alteridade, o discurso do multiculturalismo coloca-se nas antípodas do discurso nacionalista. Centrado no repúdio do Outro, o discurso nacionalista é perigoso uma vez que leva, ou pode levar, à reprodução do ódio, como formula Kristeva de forma precisa: "nationalisms, like fundamentalisms, are screens in front of this violence, fragile screens, see-through screens, because they only displace that hatred, sending it to the other, the neighbour, to the rival ethnie group. The big work of our civilization is to try to fight this hatred." (Kristeva, appud Keamey, 2004: 165-166).

Se o trabalho da civilização contemporânea é o de lutar contra o ódio, que fazer com a história do ódio que aconteceu na realidade histórica? Dito de outro modo, será que a maneira mais eficiente de promover a reconciliação e a cura das feridas do passado é o silenciamento da violência que as provocou? Se ao romancista assiste a liberdade poética que lhe permite criar mundos paralelos, o autor de um romance histórico deve ainda alguma coisa à "verdade histórica" - tal como é possível conhecê-la -, dito de outro modo, também a ficção histórica tem a responsabilidade moral e política de não produzir falsa história. A narração de uma história de violência sob uma forma idealizada, que silencia o que dói, continua fazer o trabalho de silenciamento da voz do Outro praticado pela ficção e pelo discurso nacionalista, pelo que é ainda de uma forma de triunfo da voz do mais forte sobre as vítimas da história. Produz pacificação, mas esta atinge-se, ou constrói-se, à custa do silenciamento do sofrimento e da memória do sangue. A história do ódio é, portanto, necessária à autêntica reconciliação.

As representações da expansão portuguesa como missão civilizadora heroica sobrevivem ao reconhecimento histórico da violência utilizada nesse processo. Exemplar desta persistência é 1613 (2005), romance de Pedro Vasconcelos. Sob a forma de um romance de aventuras, com as consequências na produção do sentido que o género implica, nele pode observar-se a sobreposição da matriz antiga do heroísmo português civilizador com a matriz hegemónica actual do multiculturalismo. É justamente na confluência destes dois modelos que reside 
o particular interesse deste romance: enquanto mantém a imagem herdada da expansão portuguesa, o processo de colonização é apresentado enquanto encontro de culturas.

Toda a acção se passa em 1613, como o título anuncia, entre Solor, nas ilhas das especiarias, e Goa. Espaço e tempo remetem para um epicentro de violência do Império Português, cuja benevolência o romance logra salvar. O "encontro de culturas" tem, em primeiro lugar, a configuração convencional do "amor que ultrapassa barreiras", à qual a ficção frequentemente recorre para representar conflitos da realidade histórica. Trata-se de uma estratégia que passa pela localização do mal na psicologia individual dos bem identificados vilões da história, e que deixa intactos os processos históricos que o produzem. Neste romance, a trama amorosa está figurada nas personagens de D. Manuel Álvares, capitão português da fortaleza de Solor, e de Nanu, princesa local. São basicamente três as circunstâncias históricas que vão funcionar como obstáculos à realização feliz do encontro amoroso, e que são, simultaneamente, agentes da violência: a guerra em curso contra as forças holandesas, o tribunal da Inquisição de Goa, e a união dinástica das coroas ibéricas. São circunstâncias que todos reconhecemos. É justamente durante a união dinástica que a Holanda e a Inglaterra começam a disputar a hegemonia portuguesa e espanhola no índico e no Pacífico. Em Goa estava activo um tribunal da Inquisição particularmente feroz (Bettencourt, 2004 e 1994). Ora, neste romance, a distribuição de papéis permite salvaguardar a integridade "portuguesa", significada em D. Manuel Alvares e seus coadjuvantes. Ainda segundo o modelo do romance de aventuras, o papel de vilão é atribuído aos holandeses, em especial à personagem do capitão Van de Velde, enquanto a Inquisição surge como uma ameaça apenas esboçada, e nunca materializada em personagem concreta. Por seu lado, a também muito vaga participação de agentes espanhóis na trama fornece ao romancista um bode expiatório - usando os suspeitos do costume - uma vez que são esses os responsáveis pela injustiça e corrupção generalizadas do Estado da índia.

A violência está presente, mas não deixa de ser algo inócua, devido à estratégia narrativa dominante: a narração da história como aventura. ${ }^{13}$ De facto, este modelo cria distanciamento no acto de leitura, porque o leitor identifica facilmente o carácter ficcional e inverosímil do que se conta. Neste romance encontramos os ingredientes que reconhecemos das narrativas de aventura que lemos na adolescência: heróis imbuídos de coragem física e moralmente impolutos enfrentam vilões inequivocamente malévolos, são continuamente confrontados

13 Para uma discussão do modelo da aventura como produtor de reflexão e questionamento de verdades adquiridas, veja-se Bebiano, 2004. 
com circunstâncias perigosas mas delas escapam com mais excitação do que medo, e acabam por triunfar, ou escapar para longe. D. Manuel é um herói desse tipo. Amigo dos nativos, suscita a lealdade dos seus homens pelo exemplo da sua coragem física, como se pode ver no momento em que enfrenta, de peito aberto, o fogo das tropas holandesas - "Por Deus e pela pátria! Morremos a defender o forte e a nossa honra! Mas ninguém arreda pé!" (1613: 108)

A aventura constrói um mundo e um ethos eminentemente masculinos e frequentemente é-lhe acrescentada uma trama secundária amorosa, com uma acessória figura feminina, necessária à afirmação heterossexual do herói, componente importante do modelo de masculino em causa. Ora, neste romance, consentâneo com as práticas do tempo da sua escrita, a figura feminina não se reduz ao papel de simples coadjuvante, ou ao papel funcional do feminino passivo, mas é ela própria uma figura heroica. De facto, separados na confusão da fiiga durante a invasão holandesa, Manuel e Nanu têm percursos e praticam feitos paralelos também na dimensão heroica.

Ressalvando este reajustamento às representações politicamente correctas do nosso tempo, a função desta relação amorosa é semelhante à encontrada noutros romances. Trata-se de uma fantasia sobre o passado análoga à que W. G. Sebald identifica no romance alemão do pós-guerra: a representação de uma relação amorosa entre um militar alemão e uma jovem representativa das vítimas - judia, polaca, etc. - permite, nesses romances, que o passado seja reapreciado de forma sentimental, salvando a possibilidade da bondade do lado do agressor e, simultaneamente, evitando falar da violência perpetrada sobre as vítimas, (cf Sebald, 2005: 106-107) D. Manuel e Nanu têm justamente este efeito na representação que dão do passado colonial português.

Os heróis têm coadjuvantes, como compete ao género. O principal coadjuvante é Frei Belchior, instrumental no desfecho feliz da trama. Dominicano, homem bom, é um exemplo do respeito por todas as outras culturas: aceita com naturalidade a paixão de Manuel por Nanu; acolhe Nanu quando esta se encontra em perigo e esconde-a no Convento das Mónicas, em Goa; após a queda da fortaleza de Solor, às mãos dos holandeses, organiza a fuga para as montanhas dos soldados portugueses sobreviventes, dos aldeões nativos e dos guerreiros Belos (que tinham vindo da vizinha Timor em auxílio dos portugueses); organiza a fuga dos amantes de Goa, bem como a fuga do padre Jaime, um jesuíta inverosímil. Belchior é amante de livros, leitor de Omar Khayam e de outros livros proibidos pela inquisição, e um exemplo do multiculturalismo português.

Tudo isto - fuga perante as forças invasoras holandesas ou fuga da Inquisição - é contado como se fosse uma brincadeira onde há mais excitação e prazer do que medo, do que resulta a trivialização de momentos historicamente marcados 
a sangue e ferro. Refira-se, por exemplo, o episodio em que é planeada a fuga de Goa dos amantes, e também do padre Jaime, que está sob suspeita Inquisição. Para além da parafernália habitual dos romances de aventuras juvenis - que incluem um secreto templo hindu e passagens secretas no Convento das Ménicas o diálogo entre os padres Jaime e Belchior, homens maduros na pele de jovens aventureiros, é exemplar do tom da narrativa:

Excelente! Assim poderemos ajudar D. Manuel a ir visitar a sua amada!

- E nas barbas da inquisição, do arcebispo e do vice-rei!

E ambos riram da subversão, como se fossem rapazotes a fazer asneiras." (1613: 220)

Com este diálogo reduz-se a uma simples brincadeira uma situação que seria de perigo real nas circunstâncias históricas que servem de referente. Repare-se ainda que as instituições do Estado da índia, mesmo a historicamente temível Inquisição, não são vistas como verdadeiramente ameaçadoras, uma vez que podem ser vencidas de forma simples com um plano arrojado de rapazotes. Este é justamente um dos riscos em que incorre a narrativa da história enquanto aventura: transformar aparelhos do poder danosos e letais em algo inócuo.

Entre os agentes de violência existentes no romance apenas é conferida materialidade ao invasor holandês, na personagem do capitão Van de Velde. Contraponto à figura de D. Manuel, Van de Velde é definido pelo seu comportamento bárbaro para com as populações indígenas. Planeia o desembarque em Solor de madrugada porque "Queria chegar à primeira aldeia de surpresa. Queria sangue. Muito sangue.” (1613:68). De resto, não apenas ele, mas todos os holandeses estão "bêbados de sangue" (1613: 68). A selvajaria holandesa contrasta com a bondade da acção portuguesa, representação esta que encontra maior nitidez na voz de um holandês "civilizado", Peter Comellius"14: "Vira a obra dos dominicanos, as crianças limpas, a escola arranjada que agora fumegava feita em cinzas, vira como os indígenas tinham lutado, com fervor e fé. Ali, ao sol, Peter começava a duvidar da sua missão.” (1613: 132). Na voz de um inimigo político - o que lhe confere uma autoridade maior - a colonização portuguesa emerge como prática civilizadora benéfica enquanto a violência destruidora é atribuída, por inteiro, ao adversário.

14 Cujas práticas de guerra são anacrónicas. Veja-se o duelo que tem lugar na praia, entre Comellius e D. Manuel Alvares (1613: 77), um exemplo da "guerre en dentelles" (veja-se Rui Bebiano, 2000:406), em nada consentâneo com a realidade histórica que se pretende retratar. Num romance histórico os anacronismos criam também distanciamento, uma vez que relembram a ficcionalidade do que se conta. 
O contraste entre as boas práticas portuguesas e as más práticas holandesas é ainda feito na representação da relação dos invasores com o feminino. O corpo da mulher como despojo de guerra, que pertence por direito ao vencedor, é uma representação tão antiga quanto as representações da guerra e encontra-se já na Iliada. Neste romance, a relação do europeu masculino com o corpo feminino - indígena, natural, pronto a ser possuído - é também ela diferenciada, quero dizer, também ela contribui para sublinhar o contraste entre os dois projectos coloniais. Desde logo, na triangulação Menezes / Nanu / Van de Velde: enquanto Meneses está enamorado de Nanu, que a ele se entrega voluntariamente e até o solicita, Van de Velde, por seu lado, tenta violá-la, no que não é sucedido porque ela lhe resiste de forma feroz. A violação surge aqui como forma de sinalizar a diferença entre o civilizado (português) e o bárbaro (holandês). ${ }^{15}$ A relação sexual forçada contrasta com a relação sexual consentida e legitimada pelo discurso amoroso, significando metaforicamente as duas formas em presença de relação entre a potência ocidental, significada no masculino, e a terra indígena, simbolicamente representada no corpo feminino. ${ }^{16}$

Esta figuração para as relações colonizador/colonizado não se circunscreve às personagens do topo da hierarquia das duas culturas em presença - capitão da fortaleza e princesa local - mas é alargada ao povo anónimo e ao próprio corpo das forças militares presentes, na figura de um soldado, António de Goa. Tendo morrido na resistência heroica aos holandeses, o seu funeral adquire importância enquanto representação das relações entre culturas. Vieram muitos indígenas das ilhas em redor para a cerimónia, o luto é partilhado por todos, e havia ainda "algumas mulheres que choravam mais que as outras, com filhos mestiços ao colo." (1613:103). Eis um topos da herança de Portugal no mundo: a mestiçagem. Uma mestiçagem que resulta de amores - veja-se o choro das mulheres - e não de violação, ou, dito de outro modo, encontramos aqui a persistência da mítica "diferença" da colonização portuguesa, sendo os actos de violência deslocados para outras potências coloniais.

Se o império português no oriente teve uma face negra incontomável - ou se há que escolher um bode expiatório para a "culpa" de Portugal, de forma a que tudo o resto fique impoluto e possa ser romanceado em tons suaves - essa face é encontrada no tribunal da Inquisição de Goa. O trabalho historiográfico

15 Para uma discussão do significado e função da violação nas representações da masculinidade, veja-se Howard e Rackin, 1997, particularmente 196-200 e 212-15.

16 A "feminização" do espaço colonizado, que se entrega ou é tomado pelo colonizador masculino, é topos do discurso colonial e imperial europeu, primeiro identificado por Franz Fanon em Os deserdados da Terra. 
realizado sobre a questão, mas, principalmente, a moral hegemónica nossa contemporânea, fundada na carta dos direitos humanos e na aceitação da diversidade cultural do planeta, toma a sua defesa insustentável, mesmo quando historicamente compreendida. O tribunal da Inquisição de Goa foi particularmente feroz, com um volume de processos muito acima dos tribunais correspondentes do continente português e da América Espanhola (Bethencourt, 2004: 22 e 1994, passim).

Se é consensual a representação da Inquisição enquanto página negra da Igreja Católica e do Império, não deixa de assumir configurações diversas, com consequências no acto de leitura, e em 1613 ela é apresentada como algo de exterior à máquina do Império. De resto, Vasconcelos consegue a proeza de referir a sombra ameaçadora da Inquisição, enquanto apenas nomeia frades e padres que são bondosos, cultos, tolerantes de outras culturas e mesmo parcialmente nativizados - como o Padre Jaime, um farmacêutico, que, para além do mais, mantém um Shiva Linga escondido no subsolo de uma capela cristã -, isto é, tendo adquirido algumas das práticas das culturas locais. São personagens completamente independentes da instituição, à qual não é dado corpo nem efeito de realidade. ${ }^{17}$ De facto, tanto o dominicano Frei Belchior como o jesuíta padre Jaime são figuras de intelectuais humanistas, que tentam contornar a Inquisição sem que cheguem a confrontá-la. À Inquisição nunca é dado um rosto, nem sequer um agente com nome, pelo que não chega a adquirir realidade; trata-se apenas uma sombra nos bastidores da acção, uma ameaça sem contornos. Se é preciso esconder livros e pessoas com "práticas desviantes", nunca são sequer formuladas as consequências em que ocorreriam essas pessoas caso fossem capturadas. O sofrimento calado é assim relegado para uma espécie de não-existência.

Neste romance, portanto, procede-se a um reajustamento das narrativas, ao incluir o respeito por outras culturas como contendo valores positivos, conhecimentos e práticas que teremos englobado na nossa própria cultura, enquanto, simultaneamente, se salva o heroísmo e o humanismo portugueses. O império como aventura (erótica) é um lugar de perigos, mas de perigos ultrapassáveis, até que se possa de novo usufruir dos prazeres exóticos que essas terras distantes oferecem. Independentemente do potencial inegável do género da aventura para narrar a história, há que ter em consideração que a forma que se escolhe

17 Faça-se a ressalva: as práticas inquisitórias foram muitas vezes divergentes das práticas da administração do império. Bethencourt ( 1994:245) menciona momentos de tensão, e mesmo conflito, entre o tribunal da Inquisição de Goa e o Vice-Rei e o Arcebispo, justamente por as suas práticas serem, por vezes, lesivas dos interesses dos portugueses. No entanto, o binómio “a cruz e a espada" preside à expansão, e a cristianização é parte integrante do modelo do império. 
para estruturar a matéria da história tem consequências ao nível da reflexão que daí emerge. Não falo aqui de rigor histórico, o qual pode ser maior ou menor em todo o tipo de romance que tem a história por matéria; falo daquilo que é excluído e daquilo que é sublinhado. A aventura tenderá a manter intactos os aspectos do prazer, apagando a dor, o sofrimento e as injustiças, e calando as vozes das vítimas.

\section{Goa, o amor incerto}

Goa, ou o Guardião da Aurora (2005), de Richard Zimler, é um romance que convida à leitura em contra-ponto a 1613. Zimler é um caso particular. Nascido nos Estados Unidos, reside em Portugal há alguns anos e naturalizou-se português, mas continua a escrever originalmente em inglês, o que não permite a inclusão os seus romances no corpus da literatura portuguesa. No entanto, na sua trilogia sefardita - O Ultimo Cabalista de Lisboa (1996), Goa ou o Guardião da Aurora (2005) e Meia-noite ou o Princípio do Mundo (2003) - trata a história dos judeus portugueses. A matéria de que faz a sua escrita, a sua nacionalidade de opção, e a perspectiva particular que os seus romances traduzem, justificam que o traga à colação. Estamos perante romances com uma dupla perspectiva, escritos simultaneamente de dentro e de fora daportugalidade, cujas personagens centrais são membros de diversas gerações da família Zarco, desde o progrom de Lisboa de 1506, passando por Goa no século XVII, até o Porto, no início do século XIX. Nas peripécias das suas vidas podemos observar a dupla pertença desta comunidade: simultaneamente portugueses, incluídos na nação, e judeus dela excluídos pela diferença. A narrativa da história segundo a perspectiva de uma comunidade portuguesa que foi silenciada e perseguida, isto é, uma narrativa feita a partir das margens, diverge das narrativas dominantes na nossa mitografia.

No contexto deste ensaio, dos romances de Zimler acima referidos interessame particularmente Goa ou o Guardião da Aurora, justamente porque espaço e tempo da trama são quase perfeitamente coincidentes com os que encontramos em 1613: Goa na última década do século XVI. Em Zimler, porém, encontramos uma representação bem diversa da vida no Estado da índia. Estamos perante uma narrativa que contribui para fazer - para compreender - a "história do ódio", apagada no romance anteriormente discutido.

Tiago Zarco é o narrador e protagonista do romance. Descendente de Berequias Zarco, que em 1497 fora convertido à força ao cristianismo e fugira de Lisboa para Constantinopla, ${ }^{18}$ Tiago cresce numa aldeia indiana situada perto 
de Goa mas fora da jurisdição portuguesa, com o pai, Berequias, e a irmã Sofía. São judeus praticantes e conservam, escondido em local secreto, "O Espelho que Sangra", manuscrito da autoria do bisavô Berequias. Nesse texto, os judeus portugueses são exortados a procurar protecção junto dos sultões muçulmanos e a nunca mais voltar a Portugal. Exemplarmente, o Berequias actual é calígrafo do sultão de Bijapur, trabalho no qual os filhos colaboram desde tenra idade, mantendo uma prudente distância de Goa, onde vão apenas de visita. Em Goa vive o tio Isacc, negociante cristão-novo, casado com a tia Maria, cristã-velha. Têm um filho adoptivo, Wadi, também chamado Francisco Xavier, uma criança muçulmana que ficara órfã num ataque português. Importantes são ainda a mãe de Tiago, já falecida, a ama Nupi, e a namorada Tejal, todas elas mulheres hindus. Na lista das personagens centrais é já evidente a complexidade do tecido social e das identidades híbridas em jogo.

O romance divide-se em duas partes, a primeira das quais, constituída pelos dezoito capítulos iniciais, é significativamente mais longa do que a segunda, que ocupa apenas os seis capítulos restantes. Na primeira parte, numa cela da Inquisição de Goa, entre 1591 e 1594 - entre os seus dezoito e vinte e um anos Tiago vai narrando o quotidiano na prisão. Esta é a moldura narrativa do romance; encaixada, está a narrativa da infância e da adolescência, contada a posteriori a Phanishwar, um jaina acusado de feitiçaria e seu companheiro de cela. ${ }^{19}$ A relação entre os dois níveis narrativos tem consequências na construção do significado do romance: enquanto a experiência do sofrimento constitui o presente da narração, surgindo ao leitor como o real por excelência, a felicidade vivida na infância aparece como algo definitivamente passado, distante e mesmo irreal. A partir do tempo presente na cela, a memória da felicidade perdida gera pathos e não permite alívio. Ao contrário do modelo da aventura, na qual o sofrimento surge como algo passageiro e a superar no sentido de um desenlace feliz, esta estratégia de encaixe coloca o sofrimento como o "fim da linha", impedindo a possibilidade de redenção.

Para além das diferenças na organização da trama, evidentes na comparação dos dois romances, uma segunda diferença urge comentar. Falo da ideia de heroísmo que cada um deles comporta. Enquanto que em 1613 é notória a persistência da representação tradicional de heroísmo, centrada na coragem física dos protagonistas, Goa tem por protagonista um homem comum - o que permite mais facilmente criar empatia - e encontramos o medo do sofrimento físico a negar

19 Embora o estabelecimento do tribunal da Inquisição em Goa esteja associado à presença de cristãos-novos no Estado da índia, no cômputo geral o maior número de vítimas é hindu, em regra convertidos ao cristianismo acusados de "práticas desviantes" (veja-se Boschi, 1998:446). 
a possibilidade desse tipo de heroísmo. O romance não faz, de forma alguma, a apologia da "cobardia"; distancia-se, no entanto, das representações idealizadas dos heróis, propondo uma representação bem mais verosímil das possíveis respostas de um ser humano em situações de degradação extrema. Trata-se de uma crítica a narrativas moralizantes de heroísmo, que, em vez de providenciar soluções reconfortantes, provoca inquietação no leitor. Esta crítica obtém-se particularmente na centralidade que o corpo adquire, ou, dito de outro modo, pela deslocação do centro da subjectividade para o corpo concreto do indivíduo.

Mesmo na linguagem comum dos nossos dias, a palavra "inquisição" funciona como sinónimo de horror. As celas e salas de interrogatório da instituição, bem como os autos-da-fé, com o seu cerimonial elaborado e terrível, entraram no imaginário colectivo, independentemente do grau de conhecimento histórico que cada pessoa possa ter sobre a matéria. Não é por acaso que o gótico anglo-saxónico a usa na construção dos seus mundos de pesadelos fantásticos, desvinculados do real e sem presunção de verosimilhança. ${ }^{20}$ Sendo muito mais matéria de pesadelos do que matéria de representação realista, oferece um desaño à arte do escritor que pretenda representá-la. Zimler fá-lo de forma brilhante.

O romance não encena qualquer sessão de tortura. De resto, nos quatro anos que passa preso em Goa - e mesmo nos anos que se seguem na prisão de Lisboa, na segunda parte do romance - Tiago não é torturado. A Inquisição é retratada de forma quase indirecta, muito menos nos actos praticados e muito mais nos efeitos que provoca na consciência e no comportamento das personagens. $\mathrm{O}$ que faz com que o seu poder apareça em toda a sua dimensão terrífica.

A manipulação do tempo é uma das estratégias que contribui para provocar este efeito. De facto, é quase todo o tempo feito de espera na cela, de pequenos gestos do quotidiano, o que, tal como no relato autobiográfico de Primo Levi, cria uma relação de continuidade entre o narrador e o leitor. O tempo é também preenchido pela narrativa da memória e na total ignorância em relação ao tempo "lá fora", o tempo da "acção". A espera, ou a suspensão do tempo da acção, potenciam a tensão e o medo, porque muito do tempo da espera é ocupado a imaginar o que poderá estar a acontecer e o que poderá vir a acontecer. Assim, mais do que o espectáculo da tortura, a ausência de acção funciona como uma vertente do processo de aniquilamento do humano. $\mathrm{O}$ desconhecimento como forma de violência é ainda acentuado pela maneira como a narrativa se

20 Veja-se, por exemplo, Melmoth, the Wanderer ( 1820), de Charles Maturin. Acrescente-se que o uso dos cenários da inquisição na construção dos pesadelos góticos tem uma componente política importante, na medida em que traduz, no universo da ficção, as guerras das religiões, significando - e promovendo - o medo do mundo anglo-saxónico protestante perante o catolicismo. 
centra no corpo desfeito como testemunho da tortura, sem a descrever. O caso de Berequias é exemplar. A primeira vez que Tiago o visita na prisão vê o pai "sentado no catre, de peito nu, com umas calças cinzentas grosseiras e o cabelo cortado muito cerce. Tinha nódoas escuras à volta dos olhos, que estavam inchados e quase fechados. Nos cantos da boca, havia uma crosta de sangue. A toda a roda do pescoço, uma linha de pele esgarçada. Devia ter sido uma corda a apertá-lo." (Goa: 225). "Devia ter sido": como o pai se recusa a contar o que lhe tinham feito, Tiago é levado a imaginar a cena. $\mathrm{O}$ que Berequias cala é justamente o que gera maior terror, tanto no filho como no leitor, que não se pode impedir também de imaginar, socorrido que está da iconografia da inquisição que conhece.

A representação da tortura centrada nos seus efeitos, problematiza a dicotomia corpo/espírito. Para Berequias, “a tortura muda uma pessoa. É como se eu já não soubesse quem sou quando fico aqui, deitado na escuridão. Há qualquer coisa fora de sítio em mim. A minha alma, talvez." (Goa: 227). Por seu lado Phanishwar, a outra personagem torturada no romance, desiste dos seus deuses depois de uma segunda sessão de tortura. (Goa: 83). O corpo físico destruído conduz, em ambos os casos, à destruição da subjectividade; dito de outro modo, o corpo é o sujeito.

Perante a visão destes dois homens destruídos - que acontece em momentos cronologicamente diversos na narrativa - Tiago fará tudo para fugir à dor que não chega a experimentar e fará tudo para agradar ao inquisidor (Goa: 85-90) Dito de outro modo: a subjectividade de Tiago foi também destruída. O que é que define um homem? Onde reside o sujeito? Neste romance, o sujeito é indissociável do corpo; destruído o corpo, destrói-se - ou transforma-se - tudo o resto. $\mathrm{O}$ reconhecimento do corpo como realidade incontomável e como lugar por excelência da subjectividade - que nega a subjectividade fundada no cogito - encontra-se articulado de forma lapidar na voz de Tiago: "a vontade de um homem não é nada quando comparada com a dor física.” (Goa: 83) 21

Esta concepção do sujeito como estando radicado no corpo não comporta qualquer hipótese de comportamento "heroico"; não há como "portar-se bem na prisão", para lembrar a formulação eufemística corrente entre resistentes antifascistas portugueses, a qual, justamente, coloca a subjectividade para além do corpo. Enquanto Tiago procura fugir à dor agradando ao inquisidor, Berequias fá-lo procurando a morte. Quando pede veneno para se suicidar, é no reconhe-

21 Uma vítima de tortura num outro romance de Zimler di-lo de forma mais explícita: "Pensas que não és o teu corpo. Não, o "tu" que é importante está bem dentro de ti, onde ninguém pode chegar (...) Não, tu estás ali mesmo, à superfície, onde a tua pele será arrancada em tiras que queimam." (Zimler, 2003:466). 
cimento dos limites de tolerância à dor do seu corpo: "A minha alma vai-me abandonar da próxima vez que me torturarem. Vai procurar fugir à dor e voltar a casa. Vou acabar por lhes dar os nomes que querem." (Goa: 227).

A alma destruída reflecte-se ainda na impossibilidade da solidariedade, inclusive com outras vítimas, ou potenciais vítimas, ao contrário do que acontece no modelo idealizado da aventura, onde a condição de vítima obriga à solidariedade dos homens bons. Tiago desconfia de todos os membros da família, inclusive da própria irmã, a quem ama profundamente. Desconfia até que Phanishwar fora colocado na cela para o vigiar, e só desfaz essa desconfiança quando o vê arder no auto-da-fé.

Nos romances de Zimler as instituições não são independentes das pessoas; pelo contrário, o pessoal e o público são indestrinçáveis. Na primeira parte do romance há uma galeria de vilões claramente identificados: o padre Carlos Miguel Fonseca, inquisidor; o "Analfabeto", carcereiro; Jácome Morais, o familiar do Santo Ofício que acompanha Tiago no auto-da-fé; a tia Maria, católica repressora de qualquer eventual desvio às práticas da igreja e principal suspeita da delação dos seus parentes. Nestes quatro estão representados quatro níveis de colaboração e cumplicidade de que se alimenta o mecanismo da Inquisição. Mas Zimler não divide a humanidade claramente entre bons e maus, entre carrascos e vítimas: todos são potenciais vítimas e todos podem ser colaboradores no trabalho do carrasco. Mesmo os que trabalham para a Inquisição são por ela devorados, uma vez que Tiago consegue, na segunda parte do romance, e recorrendo aos métodos que a Inquisição fomenta, lançar suspeitas sobre todos eles e perdê-los a todos. Usa, portanto, a Inquisição como instrumento da sua vingança pessoal. O Mal reside na instituição, que o semeia e fomenta em todos os indivíduos, e é aqui representada como um mecanismo que todos devora, mesmo aqueles que o sustentam. Esta disseminação do mal é ainda evidente no facto de serem cristãos-novos os delatores de (possíveis) desvios à fé. Jácome Morais, o familiar da inquisição, é cristão-novo. Como são cristãos-novos o senhor Saraiva e a mulher, que denunciam a senhora Barbosa à inquisição, por suspeita de práticas judaizantes; denunciam-na, para evitar que eles próprios fiquem sob suspeita. O heroísmo individual não é possível quando todo o tecido social está contaminado pelo mal. Não se trata, pois, de um Mal metafísico, mas um Mal que advém das circunstâncias históricas e que corrói todas as relações, todos os afectos e todas as ideias de nobreza. Mesmo o amor é incerto quando a prioridade é a sobrevivência mais básica: a do corpo, reduzido à vida nua, despido de qualquer dimensão espiritual.

Junto com o heroísmo épico da nossa herança, também a nova metanarrativa do "encontro entre culturas" é aqui questionada, numa visão nos antípodas da 
que nos é oferecida em 1613. Tiago é filho de pai judeu e de mãe hindu, e a casa da infancia é exemplo desse cruzamento, que se traduz em práticas culturais sincréticas. Existe uma estátua de Shiva lá em casa enquanto se celebram os rituais judaicos e se reza o Kadish por ocasião da morte da mãe; por via da ama, as crianças são educadas na sabedoria popular hindu e participam nos festivais religiosos da aldeia. No entanto, este sincretismo cultural pára às portas de Goa. Aí, todos os portugueses se vestem como em Portugal - com roupas inadequadas ao clima -, segregam os que são diferentes e destroem a sua cultura. A tia Maria é exemplo desse modo de ser português no Estado da índia, na forma como vigia as vestimentas e os hábitos de toda a família para que não se desviem dos caminhos da rectidão. Tejal, a menina hindu que estuda no colégio de fieiras, é segregada pelas colegas portuguesas, tal como Wadi o é, no colégio para rapazes dos jesuítas. Esta intolerância portuguesa é ainda evidente nos templos hindus destruídos, nas histórias de massacres e na clandestinidade a que são obrigadas as práticas culturais locais. E, principalmente, no corpo torturado e depois queimado do jaina, partidário de uma religião que professa a não-violência e a aceitação de todos os deuses de todas as culturas. No corpo condenado de Phanishwar está escrita, de forma simbólica e indelével, a imposição da cultura portuguesa a ferro e fogo.

Tiago suicidar-se-á, depois de se ter vingado dos culpados da sua desgraça, bem como de todos os que imagina cúmplices, embora não lhe seja possível aferir o seu grau de responsabilidade. Não lhe resta outro caminho: a máquina do império destruíra-lhe a alma ao fazer dele não apenas vítima da violência, mas ele próprio agente da violência. Nesta sua dupla natureza reside a verosimilhança maior deste romance, que não cede à tentação de oferecer explicações esquemáticas - e reconfortantes - para o problema da culpa.

$\mathrm{Na}$ representação não idealizada de vítimas e de carrascos - tanto uns, como outros, pessoas "normais" - faz-se ainda um acto de justiça para com os silenciados da mitologia nacional. Em Goa, ou o Guardião da Aurora, confronta-se a "história do ódio", no que é uma contribuição para a sua compreensão. As ficções são também formas de conhecimento, ainda que incompletas e imperfeitas. A narrativa ficará para sempre aquém do corpo e da experiência da dor; mas só pela narrativa pode haver compreensão do que, antes dela, é apenas grito inarticulado. 


\section{Bibliografía citada}

ADORNO, Theodor W. (1995) - "Kulturkritik und Gesellshaft" (1951), Petra Kiedaish (ed.), Lyrik nach Auschwitz? Adorno unddieDichter. Stuttgart: Reclam, 27-49.

agamben, Giorgio (1998) - Homo Sacer - Sovereign Power and bare Life. 1995. Stanford, California: Stanford University Press.

ALONSO, Aristides (2001) - "O grotesco. Transformação e estranhamento", Cотит, 5/16, 64-80.

ARISTÓTELES (s.d.) - Poética. Tradução, Prefácio, Introdução, Comentário e Apêndices de Eudoro de Sousa. Lisboa: Imprensa Nacional - Casa da Moeda, $6^{\mathrm{a}} \mathrm{ed}$.

BARTHES, Roland (1968) - “L’Effet de Réel.” Communications. 11: 82-89.

BEBIANO, Adriana (2004) - "A História como Aventura: entre o escapismo e o questionamento", Actas do Coloquio Internacional Literatura e Historia. Maria de Fátima Marinho (org.) Porto: Faculdade de Letras.

- (2003) - Biografias Romanceadas: a história contada como delírio. Coimbra: Faculdade de Letras. Tese de doutoramento policopiada.

- (2002) - "A invenção da raiz. Representações da nação na ficção portuguesa e irlandesas contemporâneas", Entre ser e estar: Raizes, percursos e discursos da identidade, Maria Irene Ramalho e António Sousa Ribeiro (Orgs.), Porto: Afrontamento, 503-537.

Bebiano, Rui (2000) - A Pena de Marte. O discurso da guerra em Portugal e na Europa (sécs XVI-XVIII). Coimbra: Minerva.

BENJAMIN, Walter (2003) - Origem do drama trágico alemão. Edição, apresentação e tradução de João Barrento. Lisboa: Assírio e Alvim.

- (1969) - "Theses on the Philosophy of History", in Illuminations - Essays and Reflections. Edited with an Introduction by Hannah Arendt. New York: Schocken Books.

BETHENCOURT, Francisco (2004) - "A África e a Inquisição portuguesa: novas perspectivas", Revista Lusófona de Ciências das Religiões, 5/6, 21-27.

- (1994). Historia das Inquisições. Portugal, Espanha, Itália, séculos XV-XIX. Lisboa, Círculo de Leitores.

BETHENCOURT, Francisco e Kirti Chauduri (orgs) (1998) - Historia da Expansão Portuguesa. Vol II. Do índico ao Atlántico (1570-1697). Lisboa: Círculo de Leitores.

BOSCHI, Caio (1998) - "Estruturas Eclesiásticas e Inquisição", Bethencourt, Francisco e Kirti Chauduri (orgs) ( 1998). Historia da Expansão Portuguesa. Vol II. Do Indico ao Atlántico (1570-1697). Lisboa: Círculo de Leitores, 429-455. 
HEANEY, Seamus (1975) - North. London: Faber and Faber.

HOWARD, Jean E. and Phyllis Rackin (1997) - Engendering a Nation. London: Routledge.

Ilíada (2005). Trad: Frederico Lourenço. Lisboa: Cotovia.

KEARNEY, Richard (2003) - Strangers, Gods andMonsters. London: Routledge.

KERMODE, Frank (1981) - The Sense of an Ending: Studies in the Theory of Narrative. 1966. Oxford: Oxford University Press.

LEVI, Primo (s.d.) - Se Isto é um Homem. 1958. Trad: Simonetta Cabrita Neto. Lisboa: Teorema.

LOURENÇO, Eduardo (1978) - O labirinto da saudade: psicanálise mítica do destino portugués. Lisboa: Dom Quixote.

MAGALHÃES, Isabel Allegro (2002), "Capelas Imperfeitas: Configurações literárias da identidade portuguesa”, Entre ser e estar: Raízes, percursos $e$ discursos da identidade, Maria Irene Ramalho e António Sousa Ribeiro (Orgs.), Porto: Afrontamento, 307-348.

MATURIN, Charles (2000) - Melmoth, The Wanderer. 1820. Harmondsworth: Penguin. RIBEIRO, António Sousa (2000) - "Um mundo em desagregação? Ordem, violência e o discurso da literatura na Viena de 1900”, Anselmo Borges et al (orgs.), Ars Interpretandi - Diálogo e Tempo. Porto: Fundação Eng. António de Almeida, 199-234.

SEBALD, W. G. (2005) - Campo Santo. Ed. By Sven Meyer. Trans: Anthea Bell. London: Hamish Hamilton.

ZIMLER, Richard (2005) - Goa ou o Guardião da Aurora. Trad: Manuel Resende. Lisboa: Gótica.

- (2005) - Meia-Noite ou o Princípio do Mundo. 2003. Trad: Maria Dulce Guimarães da Costa. Lisboa: Gótica.

- (1996) - O Último Cabalista de Lisboa. Trad: José Lima. Lisboa: Quetzal. 